\title{
Christus en die roos
}

\author{
Riaan Ingram \\ Departement Nuwe-Testamentiese Wetenskap \\ Universiteit van Pretoria
}

\begin{abstract}
Christ and the rose

Philo of Alexandria once stated the following truth: "Do you not see that to the prophet who truly desires to know and who asks what answer he is to give to those who question him concerning His name He says, 'I am what I am,' which is equivalent to saying, 'It is My nature to be, not to be described by name"' (Philo Mut Nom 1112). How does the theologian who hears God's answer in this regard speak when others ask him or her about God? Through a discussion with Heidegger, Bultmann and Meister Eckhart, the article explores a possible answer to this question.
\end{abstract}

\section{INLEIDING}

Tydens die afgelope eeu het filosowe, soos Nietzsche, Heidegger en Derrida 'n ander denkwyse as dié van die Westerse onto-ontologiese ${ }^{1}$ tradisie herontdek. Hierdie denkers weier om oor 'n transendente werklikheid te dink en te praat. Caputo (1986:xviii-xix) som hierdie posisie soos volg op:

The "truly divine God" is precisely the God Who recedes behind everything which is said about Him. The one thing we can say about God which suits Him is that nothing we say about Him suits $\mathrm{Him}$, that is, that He withdraws behind all names, that He has no master-name, no name which masters Him, no proper name which captures what are propria to Him. ... Or, better, God: the selfwithdrawing, that which always already remains behind, in lethe, always deferring behind the signifier. And the highest work of the soul is to let Him go, to let Him be, to remain open to the lethe, indeed to shelter Him from the fire of metaphysical conceptuality, to preserve Him in His withdrawal.

\footnotetext{
*Hierdie artikel is 'n verwerking van 'n deel van die MTh-skripsie van Riaan Ingram, voorberei onder leiding van prof dr A G van Aarde, Fakulteit Teologie, Universiteit van Pretoria (2005).

${ }^{1}$ Die beskouing dat die syn van syndes alleen in terme van die essensie of eienskappe van daardie syndes ingedink kan word (Heidegger 1998:94).
} 


\section{Christus en die roos}

So 'n benadering sou verreikende implikasies vir die teologie hê. Philo van Alexandrië het dit reeds ingesien: "Do you not see that to the prophet who truly desires to know and who asks what answer he is to give to those who question him concerning His name He says, "I am what I am," which is equivalent to saying, "It is My nature to be, not to be described by name"” (Philo Mut Nom 11-12). Wat sou die teoloog sê wanneer iemand hom of haar oor God vra? Dit is maklik om te sê dat God die "Gans Andere" is en dat God nie deur die menslike intellek verstaan kan word nie. Dit is egter moeiliker om hierdie dinge nie te sê nie.

Binne die teologie blyk dit onmoontlik te wees om so 'n uitgangspunt konsekwent te handhaaf. Daar is immers die oortuiging dat God God self deur Christus en deur die Skrif openbaar. Word die gedagte van Openbaring nie absurd wanneer enige kennis van God as onmoontik geag word nie? Waarom sal die teoloog Christologie bedryf wanneer niks oor God gesê kan word nie? Miskien moet teoloë digters wees. Die teoloog kan dan alles wat mooi is, beskryf sonder om rasioneel te probeer wees. Ons skryf dan gedigte soos die volgende een van Silesius (CW, I, 289 in Caputo 1986:61):

Die Ros' ist ohn' warum,

sie blühet weil sie blühet,

Sie acht't nicht inrer selbst, fragt nicht, ob man sie siehet".

Die teoloog kan eintlik baie ver kom met 'n gedig soos hierdie. In hierdie gedig is die roos 'n metafoor vir God, Christus en mens. Waarom, Wie en Wat is God? God blom omdat God blom. Wie, Wat en waarom is Christus? Chistus is 'n Roos, omdat God blom omdat God blom. Waarom, wie en wat is die mens? Die mens is dié een wat hierdie gedig kan skryf omdat God blom omdat God blom.

Die doel van hierdie artikel is om uit te lig dat hierdie gedig eintlik 'n omvattende stuk teologie behels. Hierdie gedig staan in 'n lang teologiese tradisie wat waarskynlik by Meister Eckhart begin het. Meister Eckhart was 'n Middeleeuse mistikus wat in 1260 gebore is. Hy word veral onthou vir sy formulering van die ontologiese verskil (Albert 1987:65, 73; vgl Caputo 1986:21,103). In die twintigste eeu het hierdie ontologie weer helder deur die denke van Heidegger en Bultmann na vore getree (Jones 1991; vgl Caputo 1986). Ek neem 'n vertrekpunt in Heidegger se denke met betrekking tot wat hy die "differensie" noem. Deur na Heidegger se saak te luister, probeer ek die saak waaroor dit hier handel in gesig kry. Daarna soek ek die saak van die ontologiese verskil deur ook na Eckhart en Bultmann in hierdie verband te 
luister. Uiteindelik vra ek na die wyse waarop Christus binne die raamwerk van hierdie ontologie in die denke aankom.

\section{IDENTITEIT EN DIFFERENSIE}

In Gelassenheit betrek Heidegger die leser by 'n gesprek van 'n wetenskaplike, 'n filoloog en 'n onderwyser wat saam op 'n pad deur die platteland stap. Terselfdertyd word die leser ingetrek in 'n gesprek vanuit die denke met betrekking tot die denke. Soos ons stap, let ons op dat die landskap om ons verander. Bome, klippe, heuwels en stroompies kom en gaan. Dinge word binne ons gesigsveld teenwoordig, maar soos wat ons aanstap, verdwyn hierdie dinge ten einde weer vir ander dinge plek te maak (Heidegger 1969:63). Dit is asof die landskap voortdurend uitkom om ons te ontmoet, maar dan weer wegraak (Heidegger 1969:66). Die landskap in die geheel daarvan word nooit teenwoordig nie. Ons ervaar alleen die uitkom en terugkeer van die dinge van die landskap. Ons omgewing word voortdurend vernuwe (Heidegger 1969:65-66). In die "afwesigheid" van 'n landskap as sodanig, kan ons eintlik nie van 'n landskap praat nie. Die wandeling word eerder 'n "veromgewingliking" van 'n omgewing wat uitkom, vir 'n wyle vertoef, maar dan weer terugkeer na 'n geheime skuiling (Heidegger 1969:66). So is ons denke ook 'n opening waardeur gedagtes na vore tree en weer wegraak. Deur "veromgewingliking" word ons wandeling 'n ervaring van 'n "waaruit" en "waarheen" van dit wat in ons denke inkom en uitgaan. Sodoende dring die aard van "veromgewingliking" die gedagte van 'n "waaruit" en "waarheen" aan ons denke op. Ons kan nie anders as om te vra nie: Waaruit tree dit wat ontsluit word, na vore en waarheen keer dit weer terug (Heidegger 1969:67)? Ons kan egter nie sê nie, want die "waaruit" en "waarheen" is uit en heen. Enersyds is daar 'n verskil tussen dit wat "veromgewinglik" word en dit wat "veromgewinglik". Eersgenoemde is "hier". Laasgenoemde is "uit" en "heen". Andersyds is hierdie verskil nie 'n skeiding nie. Die een word vanuit die ander bepaal. Dit wat binne die denke na vore tree, is nie op sigself genome volkome nie, aangesien 'n "waaruit" en "waarheen" daardeur geïnsinueer word. Dit waaruit die denke na vore tree, is ook nie outonoom nie aangesien dit alleen met betrekking tot die oorkoming van die "hier" van die denke "uit" en "heen" is.

In Identität und Differenz stel Heidegger dieselfde saak vanuit 'n ander hoek aan die orde. Hy belig die verskil tussen syn ("dit-wat-veromgewinglik") en synde ("dit-wat-veromgewinglik-word") deur 'n kritiek van die identiteitsbeginsel. Volgens Heidegger $(2001: 13,16)$ is hierdie beginsel ontologies van aard. Hy stel die saak soos volg: 


\section{Christus en die roos}

Der Satz der Identität gibt sie uns, wenn wir sorgsam auf seinen Grundton hören, ihm nachsinnen, statt nur leichtsinnig die Formel "A ist A" daherzusagen. Eigentlich lautet sie: A ist A. Was hören wir? In diesem "ist" sagt der Satz, wie jegliches Seiende ist, nämlich: Es selber mit inm selbst dasselbe. Der Satz der Identität spricht vom Sein des Seienden. Als ein Gesetz des Denkens gilt der Satz nur, insofern er ein Gesetz des Seins ist, das lautet: Zu jedem Seienden als solchem gehört die Identität, die Einheit mit inm selbst

(Heidegger 2001:16)

Die identiteitsbeginsel identifiseer syn met identiteit (Heidegger 2001:16). 'n Mens sou kon sê dat hierdie beginsel identiteit as 'n kenmerk van die syn aan die orde stel (Heidegger 2001:19). So gesien lui die beginsel: Syn is identiteit. Die hipotetiese vorm lui: Indien syn, dan identiteit. Identiteit word die moontlikheidsvoorwaarde van syn. Die identiteitsbeginsel hoort by daardie denkraamwerk wat Heidegger die onto-ontologie noem. Die term "ontoontologie" is 'n samestelling van die terme "onties"2 en "ontologies"3. Dit dui op daardie soort denke wat 'n ontiese antwoord op die ontologiese vraag gee (Heidegger 1962:94). Hierdie denke word in die volgende stelling van Descartes (1911b:240) weerspieël: "But yet substance cannot be first discovered merely from the fact that it is a thing that exists, for that fact alone is not observed by us. We may, however, easily discover it by means of any one of its attributes because it is a common notion that nothing is possessed of no attributes, properties, or qualities." Hieruit is dit duidelik dat Descartes dit onmoontlik vind om die verskil tussen syn en identiteit te dink.

Hierdie beskouing hou egter nie water nie. Syn en synde ontsluit hulleself nie in terme van hulle eenheid vir die denke nie. Syn en synde word alleen in terme van hulle differensie vir die denke toeganklik. Die twee kan alleen in hulle verskil van mekaar gedink word (Heidegger 2001:59). Synde beteken "dit wat syn" en syn beteken "dat die synde is". Die een gaan nie op in die ander nie, maar bepaal die ander deur nie in die ander op te gaan nie. Heidegger (2001:19) formuleer die verband tussen syn en identiteit soos volg: "Das Sein ist von einer Identität her als ein Zug dieser Identität bestimmt." Hierdie stelling bevat die volgende proposisie: Identiteit is syn. Die hipotetiese vorm lui: Indien identiteit, dan syn. Syn word die moontlikheidsvoorwaarde van identiteit. Die saak van die identiteitsbeginsel word egter ook in Heidegger se formule opgeneem. "Das Sein ist von einer Identität her als ein Zug dieser

\footnotetext{
${ }^{2}$ Die ontiese hou verband met die dinge wat is, ongeag die syn van die dinge wat is (Flew \& Priest 2002:289).

${ }^{3}$ Die ontologiese hou verband met die syn van die dinge wat is, ongeag die aard van hierdie dinge (Flew \& Priest 2002:291).
} 
Identität bestimmt." Syn tree vanuit die synde na vore. Sodoende blý identiteit ook die moontlikheidsvoorwaarde van syn. Nóg syn nóg identiteit word verabsoluteer. Die een word vanuit die ander gedink. Identiteit is dit wat deur die syn bewerkstellig word, en syn word ontsluit vanuit dit wat daardeur bewerkstellig word.

Ons tref syn en synde altyd in terme van 'n differensie aan (Heidegger 2001:59). Synde beteken dit wat syn, en syn beteken dat die synde syn (Heidegger 2001:60). Die differensie van syn en synde behels egter geen relasie nie (Heidegger 2001:59). 'n Relasie is 'n toevoegsel (Heidegger $2001: 60$ ). Dit is 'n voorstelling van die verband tussen twee sake wat reeds buite om hulle relasie vir die denke toeganklik is. Die differensie tussen syn en synde is egter meer oorspronklik as so 'n toevoegsel. Nóg syn nóg synde kan buite om die differensie gedink word. Syn en synde verskyn alleen vanuit die differensie (Heidegger 2001:61). Beteken dit dat die differensie die grond van die syn is? Wanneer ons hierdie vraag vra, is ons besig om die verband tussen syn en differensie as 'n relasie voor te stel. Aangesien die syn alleen vanuit die differensie na vore tree, kan die syn nie iets wees wat buite om die differensie toeganklik is nie. Verder syn die differensie self. Die differensie tree vanuit die syn na vore (Heidegger 2001:62; vgl ljsseling, nawoord in Heidegger 2001:96). Waar laat dit die denke in die poging om die syn te dink? Syn betree die denke as die differensie van sigself en die synde.

In soverre die differensie self ook syn, kan ons die saak soos volg formuleer: Vanuit sigelf differensieer die syn sigself en die synde. In hierdie verband stel Heidegger (2001:62) die volgende: "Sein des Seienden heißt: Sein, welches das Seiende ist." Hy belig hierdie stelling dan deur die volgende stelling: "Das 'ist' spricht hier transitiv, übergehend." Dit beteken dat "welches das Seiende ist" nie 'n kenmerk van die syn is nie, maar iets wat deur die syn bewerk word. Verder is die "ist" 'n ontologiese term. Die "bewerking" is ' "bewerkstelliging". Die stelling "Sein, welches das Seiende ist" beteken eintlik "syn laat wees wat ook al die synde is". In kort: Syn laat wees die synde (ljsseling, nawoord in Heidegger 2001:96). Syn laat wees die synde egter nie op so 'n wyse dat syn in 'n synde oorgaan en self 'n synde word nie (Heidegger 2001:62). Syn laat wees die synde deur sigself en die synde te differensieer. "Dit wat veromgewinglik", gee (kom uit) en neem (gaan heen) met betrekking tot die ontslotenheid (die "hier") van die synde. Sodoende ontsluit die syn sigself deur die synde. Maar hierdie ontsluiting is "uit" en "heen". Deur sigself te ontsluit, verberg die syn sigself. Ontsluiting en verberging hoort saam. Heidegger (2001:62) stel die saak soos volg: "Sein zeigt sich als die entbergende Überkommnis. Seiendes als solches erscheint in der Weise der in die Unverborgenheit sich bergenden Ankunft". Die syn is 


\section{Christus en die roos}

telkens "geborgen anwähren" (Heidegger 2001:62). Die syn "is" die synde sonder om self ooit synde te word.

Die bron van die synde is nooit self ' $n$ synde nie. Hierdie saak van die differensie het verreikende gevolge vir die denke en die denke se houding jeens die bron van die denke. Heidegger se ontologie van die differensie ondermyn die fondamente waarin alle rasionele denke kwansuis gegrond sou wees. Die rasionaliteit waarna ek hier verwys, het betekenis binne die raamwerk van die Griekse Logos-ontologie. Op ontiese vlak is daar sekerlik groot verskille tussen moderne rasionaliteit en die wyse waarop die antieke Grieke die wêreld probeer verstaan het. Op ontologiese vlak is moderne rasionaliteit en die Griekse Logos-ontologie egter dieselfde. Beide werk binne die raamwerk van die onto-ontologie (Heidegger 2001:55-56). Heidegger (2001:69) se vernaamste probleem met die Logos-ontologie is daarin geleë dat hierdie soort denke vanuit die differensie dink sonder om op die differensie as sodanig ag te slaan. Wanneer ons vanuit die differensie op die differensie ag slaan, dink ons van 'n bron en van dit wat vanuit hierdie bron na vore tree. Verder dink ons hierdie bron as 'n ontsluitende verberging. Binne die raamwerk van die Logos-ontologie word die bron as grond gedink en word dit wat vanuit die bron na vore tree as die gegronde gedink. In laasgenoemde geval word grond as 'n teenwoordigheid - dit wil sê: as 'n synde - gedink. In hierdie verband stel Heidegger (2001:68) dat "[d]as Gründen selber erscheint innerhalb der Lichtung des Austrags als etwas [my aksentuering] ...". Die vraag na die bron van die synde word die vraag na die een of ander fundamentele synde. Sodoende verval die verbergende wese van die bron in vergetelheid.

Heidegger belig die betekenis van die grond waarvan hier gepraat word deur Leibniz se beginsel van genoegsame rede soos volg te herformuleer: Niks is indien daar nie 'n genoegsame rede daarvoor gegee kan word nie (Caputo 1986:60). Die syn van 'n synde hang daarvan af of dit oor 'n grond beskik al dan nie. En, die rede het die taak om te bepaal wat daar is, deur vas te stel wat begrond kan word. Daar word veronderstel dat spesifieke sake altyd in terme van iets meer algemeen of meer primêr begrond kan word (deduksie). Dat klippe val, word verklaar aan die hand van gravitasiewette.

Verder word veronderstel dat elke algemene grond weer in spesifieke sake gegrond kan word (induksie). Die gravitasiewette word bevestig deur die verskynsel dat klippe altyd val wanneer dit vanaf 'n hoogte losgelaat word. Universele syndes impliseer spesifieke syndes. Spesifieke syndes impliseer universele syndes. En, alles wat is, behoort tot hierdie rasionele orde. Anders gestel: Niks wat is, behoort nie tot hierdie rasionele orde nie. Die Grieke het hierdie rasionele struktuur die Logos genoem. Uit die Logos spruit alles wat is 
met deduktiewe noodwendigheid voort, en deur alles wat is, word die Logos as die fundamentele premisse van alles geïmpliseer (Heidegger 2001:56,67; vgl Bultmann 1969:294, Caputo 1986:79). Volgens Heidegger is hierdie rasionele orde niks anders as die produk van die mens se poging om alles in die mens self te grond nie (Caputo 1986:73). Deur sy rede wil die mens homof haarself van sy of haar wêreld verseker.

Wanneer ons vanuit die differensie op die differensie ag slaan, is daar egter geen grond nie. Die synde tree vanuit die bron daarvan na vore as 'n verbergende aankoms. Deur die synde word die bron van die synde verberg. Sodoende word die synde self ook verberg. Wie kan die volheid van dit wat moontlik kán wees, weet? Die mens kan nooit van sy of haar wêreld seker wees nie. In hierdie verband stel Heidegger (2001:65): "Wie es, das Sein, sich gibt, bestimmt sich je selbst aus der Weise, wie es sich lichtet." Vanuit sigself differensieer die syn sigself en die synde. Wat is die bron van dit wat ontslote is? Ons kan nie sê nie, want die syn differensieer sigself en dit wat ontslote is. Wat is die volheid van dit wat ontsluit word? Daar is geen antwoord nie, want die synde is 'n verbergende aankoms. Sodoende word die vrae waardeur ons ons wêreld seker wil maak, onsinnig. Ons wêreld word soos die roos waarvan Silesius dig: "Die Ros' ist ohn' warum, sie blühet weil sie blühet, Sie acht't nicht ihrer selbst, fragt nicht, ob man sie siehet" (CW, I, 289 in Caputo 1986:61). Vir Heidegger beteken Silesius se gedig nie dat die "omdat" van die wêreld verdwyn nie. Dit beteken alleen dat dit onsinnig is om na die rede van die wêreld te vra en om sodoende na 'n "sekere" wêreld te soek (Caputo 1986:64). Silesius ontken die "warum" van die roos. Die "weil" blý. Elke saak is in sigself gegrond (Caputo 1986:64). "Die Ros' ... blühet weil sie blühe." Die denke wat op die differensie ag slaan, besef dat dit aan die syn oorgelewer is. Hierdie soort denke beskik alleen oor die sekerheid dat dit geen reg het om aan die syn voor te skryf met betrekking tot wat is en mag wees nie. "Die Ros' ... acht't nicht ihrer selbst, fragt nicht, ob man sie siehet". Dit wat in die denke aankom, gee nie om of dit gegrond word al dan nie. Dit is telkens reeds wat dit is, omdat dit is.

\section{GOD EN IDENTITEIT}

In hierdie paragraaf stel ek twee teoloë aan die orde wat op 'n soortgelyke wyse as Heidegger vanuit die differensie op die differensie ag slaan. Nóg Meister Eckhart nóg Bultmann dink aan die bron van die synde as 'n fundamentele synde. 


\section{Christus en die roos}

\subsection{Meister Eckhart}

Albert (1987:65-77) som Eckhart se denke in terme van twee teses op. Enersyds bevat Eckhart se denke die volgende tese: "Das Sein ist Gott". (Albert 1987:65; vgl Caputo 1986:103). Eckhart (Dominica I Post Trinitatem $\mathrm{VI}, 1,53)$ gaan so ver as om te sê dat “... alles Sein aller Dinge ist er [God] selbst ...". Andersyds weerspieël Eckhart se werk ook die volgende tese: "Gott ist kein Sein" (Albert 1987:73; vgl Caputo 1986:21). In hierdie verband stel Eckhart (LW V 45,3 in Albert 1987:73) dat "Gott kommt also nicht das Sein zu ...". God is beide syn en "niks". In die geval van Eckhart bevat hierdie gedagte geen interne kontradiksie nie. Die term "Sein" het in hierdie twee teses nie dieselfde betekenis nie. Eckhart (LW IV in Albert 1987:67) onderskei tussen twee "soorte" syn wanneer hy sê dat "[m]an muß anders denken ... über das reine und einfache Sein ohne jegliche Hinzufügung als über das Sein dieses und jenes Seienden". Eckhart is besig om 'n onderskeid tussen goddelike syn en kreatuurlike syn te maak. Die skepsel syn altyd in die vorm van 'n bepaalde identiteit, terwyl God bo enige identiteit verhewe is (Albert 1987:72; vgl Caputo 1986:103). God is "reine und einfache Sein" en sodoende is God nie "Dies-und-das-Seiende" nie. Alhoewel hierdie twee teses nie in 'n kontradiksie met mekaar is nie, behels dit wel 'n paradoks. Die syn van alles is God, sonder dat God self enigiets is. Eckhart (In Festo s. Trinitatis IV,1,28) verwoord hierdie paradoks wanneer hy stel dat “... wie er [God] selbst ununterschieden ${ }^{4}$ in seiner Natur und trotzdem von allen Dingen schlechthin unterschieden ist, so ist in ihm alles zugleich in größter Unterschiedenheit ${ }^{5}$ und ununterschieden ....". Alles is God sonder dat God enigiets is.

Wanneer die twee dimensies van hierdie paradoks van mekaar geskei word, gaan die ontologiese betekenis van Eckhart se werk verlore. Deur die paradoks in Eckhart se ontologie te ignoreer, het sy tydgenote hom as 'n panteïs afgemaak terwyl sommige Marksiste hom al vir sy ateïsme geloof het (Albert 1987:70-71). Hierdie beskuldiginge hou egter alleen water wanneer Eckhart vanuit 'n onto-ontologiese hoek geïnterpreteer word (Albert 1987:70; vgl Caputo 1986:135). Binne die raamwerk van hierdie ontologie word syn en synde met mekaar geïdentifiseer (Heidegger 2001:16). Die onto-ontologie vind dit onmoontlik om die differensie tussen syn en synde te dink. Met betrekking tot Eckhart se werk beteken dit dat die spanning tussen die ongedifferensieerde en die gedifferensieerde misgekyk word. Vir die ontoontologiese denker is identiteit die moontlikheidsvoorwaarde van syn.

\footnotetext{
4 "Ununterschieden" dui op die afwesigheid van "differentia" - dit wil sê op die afwesigheid van dit wat ' $n$ bepaalde saak anders as ander sake maak (Flew \& Priest 2002:106).

5 "Unterschiedenheit" het betrekking op dit wat wel oor ' $n$ bepaalde essensie wat dit van ander sake onderskei, beskik.
} 
Wanneer Eckhart stel dat syn God is, dink die onto-ontologiese denker dat Eckhart God met daardie "soort" syn identifiseer wat met die identiteit van skepsels sinoniem is. Sodoende dink hulle dat dit Eckhart se bedoeling is om God aan die totaliteit van die skepping gelyk te stel. Die uiteinde is dat Eckhart as 'n panteïs geïnterpreteer word. Wanneer Eckhart stel dat God nie hierdie of daardie bepaalde synde is nie, dink die onto-ontologiese denker weer dat Eckhart die syn van God ontken. Vir die onto-ontologiese denker is syn immers sinoniem met die syn van hierdie of daardie bepaalde synde. Eckhart se bedoeling is egter nie om die syn van God te ontken nie, maar om te sê dat God nie die syn van hierdie of daardie bepaalde synde - dit wil sê van identiteit - is nie (In Festo s. Trinitatis IV, 1, 28). God is eerder die ongedifferensieerde wat "... von allen Dingen schlechthin unterschieden ist ..." (In Festo s. Trinitatis IV, 2, 28).

Eckhart se onderskeid tussen syn en synde beteken nie dat hierdie twee sake niks met mekaar te make het nie. Sy tese is dat die goddelike syn die bron van die synde is, maar sonder om self die synde te wees (In Festo s. Trinitatis IV, 2, 29; vgl Albert 1987:71; Caputo 1986:135). Die ontoontologiese gewoonte van ons denke om die syn as 'n synde te verstaan, maak dit vir ons moeilik om hierdie ontologiese verskil te dink. In die poging om die ontologiese verskil te dink, gebeur dit maklik dat ons die syn maar net as 'n synde dink wat op 'n onvolkome wyse in die denke aankom. Sodoende beland ons in 'n perspektivistiese omgewing. Ons dink aan die ontslotenheid as 'n oogpunt vanwaar ons die bron gedeeltelik in die oog kan kry. Dat Eckhart se denke geen perspektivisme behels nie, word duidelik wanneer ons sy denke met dié van Plato vergelyk. In hierdie verband is Jaspers (1983) se eksistensialistiese interpretasie van Plato die mees interessante. Soos Eckhart, is Plato van mening dat syndes nie 'n bestaan in sigself het nie. Volgens Plato kom syndes alleen in die denke aan wanneer dit met hierdie of daardie bepaalde universele essensie of Idee geïdentifiseer word (PI Phaed 18.a). Dit wat in die denke aankom, ontleen die bestaan daarvan aan 'n bron wat die denke transendeer. Tot en met hierdie punt is die verskil tussen Plato en Eckhart duidelik. Eckhart sien die bron van syndes nie as hierdie of daardie bepaalde essensie nie, maar as dit wat sonder enige essensie is. Tog is daar in hierdie verband ook 'n ooreenkoms tussen Eckhart en Plato. In beide gevalle is daar sprake van 'n verborgenheid en 'n ontslotenheid.

Wanneer ons Plato se ontologie bedink, behoort ons nie alleen dit wat Plato sê in ag te neem nie. Ons behoort ook let op die wyse waarop hy dit sê. Vir Plato is die lewe 'n voortdurende dialoog. En, in 'n dialoog word daar rekening gehou met dit wat geslote is. Die dialoog is juis 'n soeke na dit wat geslote is en gaan sodoende uit van die veronderstelling dat daar in die 


\section{Christus en die roos}

ontslotenheid steeds 'n verborgenheid skuil. Vanuit 'n eksistensialistiese hoek som Jaspers (1983:26-27) Plato se werk soos volg op: "Wohl aber wird ein sachlich geführtes Sprechen in Frage und Antwort (in Untursuchung) möchlich, um einen Weg zu gehen ... auf dem jene letze Erleuchtung zur Führung gelangt, ohne Gegenstand zu werden. Erkenend und wissend zu leben, is die höchste Möchlichkeit des Menschen". So gesien, is Plato se filosofie 'n lewensoriëntasie met betrekking tot die waarheid, wat dit nie ten doel het om hierdie waarheid tot objek te maak en finaal te bemeester nie. Die lewe is 'n kennende weg en nie 'n toestand van kennis nie. Daar is dus sprake van 'n verborge bron wat in die denke aankom sonder om ooit in die denke op te gaan. Hierdie denke is so naby aan die denke van Eckhart, maar tog ook so ver. Plato postuleer 'n bepaalde synde as die verborge bron van dit wat in die denke aankom. Hy benoem hierdie bron. Dit is die Idee van die Goeie (PI Rep 6.509.b). Daar is iets wat op 'n verbergende wyse in die denke aankom. lewers daar buite is daar 'n bepaalde essensie wat besig is om sigself deur die denke te ontsluit. Eckhart sê egter dat die bron van die denke "niks" is nie. Hy postuleer geen synde buite die denke nie. Hy loop Plato se Idee van die Goeie trompop wanneer hy stel "... daß (Begriffe wie:) gut, wahr, Wahrheit, Güte und ähnliches nicht eigentlich von Gott ausgesagt werden können, weil sie (etwas zu Gott) hinzufügen oder eine Zahl in den Gedanken oder die Begriffsbildung oder die Idee einführen (In Festo s. Trinitatis IV, 2, 30).

Vir Eckhart is God die bron van alles in soverre God alles liefhet. "Liefhê" funksioneer hier as 'n oorganklike werkwoord. Dat God alles bewerkstellig, beteken vir Eckhart dat God alles "lief". In hierdie verband stel Eckhart (Dominica I Post Trinitatem VI, 1, 54) die volgende: "Zweitens ist und heißt Gott hauptsächlich insofern Liebe, weil er es ist, den alles liebt und sucht, das lieben kann. Weiter: er ist es der allein von allen und in allen geliebt und gesucht wird. Weiter: er ist es, in dessen Suchen und Lieben alles existiert, was ist oder sein kann." Eckhart maak nog 'n stelling wat dit moontlik maak om die wyse waarop hy God as die bron van die skepping beskou met die Logos-ontologie te vergelyk. Hy sê dat "... die Liebe einigend und ausströmend ist (Dominica I Post Trinitatem VI, 1, 52). Hierdie frase is byna net so op die Logos-ontologie van toepassing. Volgens die Logos-ontologie vloei alles met logiese noodwendigheid uit die Logos voort, en die Logos is die fundamentele premisse waarin alles gegrond is. In eersgenoemde stelling van Eckhart hoor ons egter iets wat vir die Logos-ontologie vreemd is: God "... ist es, in dessen Suchen und Lieben alles existiert, was ist oder sein kann [my aksentuering] ..." (Dominica I Prima Post Trinitatem VI, 1, 54). Eckhart stel nie alleen dat God die bron is van alles wat is nie. Hy voeg by dat God ook die bron is van alles wat kán wees. Die bron kan ook "laat wees" of "lief" 
wat daar nie is nie. Al sou 'n mens alles wat is tot by die wortel daarvan kon oopgrawe, sou jy nog nie die bron daarvan vind nie. Die bron van dit wat is, word nie deur dit wat is, geïmpliseer nie. 'n Mens kan God nie vanuit dit wat is, bepaal nie. Die bron van dit wat is, is nie in dit wat is, gegewe nie. Anders gestel: God laat wees dit wat is sonder om daarin op te gaan.

Selfs al is die Idee van die Goeie verborge, kan Plato die wêreld in terme van die die Idee van die Goeie verstaan (PI Rep 6.509.b). Hy kan ook spekuleer oor die aard van die Idee van die Goeie (PI Rep 6.509.b). Vir Eckhart is daar egter "niks" om oor te spekuleer nie. Daar is niks om met betrekking tot God te dink nie. Die wêreld gebeur nie op grond van iets wat daar agter skuil nie. Die gedagte wat deur Silesius se gedig van die roos tot uitdrukking kom, is oorspronklik deur Meister Eckhart ontsluit (Caputo1986:98). In hierdie verband stel Eckhart (In Festo s. Trinitatis IV, 1, 21) dat "... alle Wesen aus Gott und durch Gott wirken ...", maar dat "[in] ihm aber gibt es kein Wegen" (In Festo s. Trinitatis IV.1.21). "Die Ros' ... blühet weil sie blühet". Dit wat is, word "gelief" omdat dit "gelief" word. Daar is niks meer om te dink nie. Daarom stel Eckhart (Dominica I Post Trinitatem VI.1.52) dat "... die Liebe beginnt da, wo das Denken aufhört."

\subsection{Bultmann}

'n Ooreenkoms tussen die ontologie van Heidegger en Bultmann is daarin geleë dat hulle hulleself op 'n soortgelyke wyse van die Griekse Logosontologie distansieer. In Der Begriff des Wortes Gottes im Neuen Testament neem Bultmann hierdie lyn van denke op wanneer hy die Griekse Logos-leer teen die Nuwe Testament se beskouing van die Woord van God afspeel. Die Logos waarvan hy hier praat, is dieselfde Logos as die waarvan Heidegger in Identität und Differenz praat. Hierdie Logos is daardie synde wat beide die basis en die rede van alle syndes is. Dit is die noodwendige ordening van alles wat noodwendig deur die denke van die mens teenwoordig is (Bultmann 1969:294). In soverre hierdie Logos dit is wat noodwendig aangekom het, is dit iets wat gekommunikeer en telkens bevestig kan word (Bultmann 1969:293). In teenstelling hiermee het Bultmann ' $n$ Woord in gedagte wat 'n skeppende uitwerking het (Bultmann 1969:279). Soos die differensie waarvan Heidegger praat, "transendeer" hierdie Woord dit wat altyd reeds deur Dasein ontsluit is. Die Woord van God stel die mens voor die keuse om sy of haar ou selfverstaan te laat vaar, of om God toe te laat om hom of haar te vorm (Bultmann 1969:303, 305). Die Woord van God konfronteer die mens met die moontlikheid om deur die Wil van God oorkom te word. Hierdeur kom die Wil van God egter nie finaal en voltooid in die mens aan nie. Die Woord van God is nie ' $n$ instruksie of 'n etiese leer waarop die mens ' $n$ greep kan kry nie. Dit is 


\section{Christus en die roos}

ook nie kennis wat alle moontlikhede vir die mens uitlê en teenwoordig stel nie (Bultmann 1969:301). Anders as die Griekse Logos, kommunikeer hierdie Woord nie iets wat aangekom is nie. Dit lê nie 'n inhoud voor waaroor daar gereflekteer kan word nie. Die Woord differensieer sigself van dit wat aangekom is deurdat dit telkens die uitdaging en die moontlikheid van 'n oorkoming is van die wyse waarop die mens hom- of haarself reeds verstaan (Bultmann 1969:301).

Wat is die betekenis van hierdie ooreenkoms tussen wat Heidegger die differensie en Bultmann die Woord van God noem? Tydens 'n ontmoeting met die Marburgiane in 1960 gee Heidegger die volgende raad aan teoloë wat sy denke wil benut: "Syn : denke :: God : gelowige denke" (Caputo 1986:143; vgl Jones 1991:108). Volgens Jones (1991:108) belig hierdie analogie die verband tussen Bultmann en Heidegger se denke met betrekking tot die ontologiese verskil. Beide hierdie denkers wil die absolute realiteit verwoord as 'n skeppingsgebeure van selfopenbaring. In die geval van Heidegger heet hierdie gebeure die differensie van syn en synde of syn en denke. Vir Bultmann behels dit die eskatologiese gebeure van Christus (Jones 1991:108). In sy kommentaar op die Johannesevangelie verwoord Bultmann hierdie saak deur 'n ontmitologisering van die Logos-motief in Johannes1. Die objektiverende stellings van Johannes1:1-2 met betrekking tot God en die Logos dui vir Bultmann op die ervaring dat Dasein soms deur 'n werklikheid gekonfronteer word wat 'n oorsprong buite Dasein het. Die Logos is die openbaring van God binne die historiese werklikheid van Dasein, maar op so 'n wyse dat die wese van God nie in hierdie openbaring opgaan nie (Bultmann 1941:18). Dat God werklikwaar deur God's Woord binne Dasein ontmoet kan word, sónder dat die wese van God direk en volkome hierdeur in Dasein teenwoordig word, is 'n paradoks (Bultmann 1941:17). Die syn van God "transendeer" God se openbaring in die historiese werklikheid van Dasein. Tog word God as sodanig werklikwaar binne die historiese werklikheid van Dasein openbaar. Hy is nie alleen "offenbarende Gott" nie. Hy is "sich offenbarende Gott” (Bultmann 1941:18).

Soos die syn waarvan Heidegger praat, word God hier as die bron van die synde beskryf. As "sich offenbarende Gott" is God die bron van die synde op so 'n wyse dat God in die skepping aankom. Tog "is" (oorganklik) God nie die skepping op so 'n wyse dat God in die skepping opgaan nie. God blý die skepping "transendeer". Die aankoms is ook telkens 'n oorkoming. Die Logosgebeure - die skeppende openbaring - is 'n bergende ontsluiting. Net soos die syn sigself en die synde differensieer, differensieer God sigself en die skepping deur die Logos-gebeure. Bultmann se beskouing van die Logosgebeure stem ook ooreen met Eckhart se perspektief. Die paradoks waarvan Bultmann (1941:17) praat - naamlik: dat God God self enersyds in die historiese werklikheid openbaar, maar dat God God self andersyds ook nie in 
die historiese werklikheid openbaar nie - stem ooreen met Eckhart se paradoksale tese - naamlik dat syn God is en dat God nie syn nie. Syn is God in dié sin dat God die moontlikheidsvoorwaarde of die bron van alle syndes is, maar God is hierdie bron op so 'n wyse dat God self nooit 'n synde word nie.

\section{3 'n Disanalogie}

Die paradoks wat binne Eckhart en Bultmann se denke na vore tree, stem ooreen met die differensie waarvan Heidegger praat in soverre beide paradoks en differensie 'n ontologiese verskil behels. Dit verskil egter in soverre Eckhart en Bultmann die paradoks in geloof benader, terwyl Heidegger, die filosoof, nie nodig het om hierdie geloofsprong te maak nie. Vir Heidegger het syn geen realiteit buite om die synde nie (Caputo 1986:184). Dit beteken dat hy alleen van syn vanuit die differensie praat. Van syn kan daar alleen gesê word dat dit sigself as bron en die synde vanuit ' $n$ differensie differensieer. Die bron as sodanig is ' $n$ woestyn. Dit is 'n ongenaakbare onthullende verberging sonder sin.

Released from all teleological, eschatological story-telling, the history of Being is such as it is, an unfolding of dif-ference, the unfolding of the manifold senses of being. There are many senses of Being, many truths of Being, playing themselves out, playing because they play, none of which enjoys special privileges and canonical authority. A-letheia: that means, the play of the epochs, released from all metaphysical rule, springing up from the withdrawal only to recede again. ... It underlines the "danger" to which thinking and Being are exposed, the uncertainty which inhabits the history of Being. The kingdom is in the hands of a child playing a game of draughts with the epochs. And it is the mystery of that play, of what is withdrawing in that play, that seems to me what is deepest in Heidegger.

(Caputo 1986:xxiii-xxiv)

Die boodskap is duidelik: Moenie oor dinge spekuleer waarvan jy niks weet nie. Ons ervaar die syn alleen soos wat dit sigself deur die eeue heen deur die denke onthul en verberg. Uit die wyse waarop die syn sigself laat aankom, kan ons aflei dat dit nie veel van 'n doel in gedagte het nie. Dit is al.

In Welchen Sinn hat es, von Gott zu reden? stel Bultmann (1933:33) die ontologiese verskil soos volg aan die orde: "Wir können nicht über unsere Existenz reden, da wir nicht über Gott reden können; und wir können nicht über Gott reden, da wir nicht über unsere Existenz reden können. Wir können nur eins mit dem andern. Könnten wir aus Gott von Gott reden, so könnten wir auch von unserer Existenz reden, und umgekehrt." Die differensie word 
duidelik in hierdie stelling weerspieël. Nóg God nóg die denke word buite om die differensie ontsluit. Daarna stel Bultmann (1933:33) Heidegger se skeptisisme direk aan die orde: "Aber folgt nicht vielleicht aus der geschilderten Situation, daß wir Sünder sind, etwas ganz anderes, nämlich daß wir überhaupt nicht reden sollen?" Hoe kan die denke wat juis van God gedifferensieer word ooit van God dink? Bultmann (1933:30) gee dieselfde antwoord as Heidegger: Ons kan nie. Ons spreke van God is altyd sondig omdat ons deur hierdie spreke gryp na iets wat nie ons s'n is om te gryp nie. Op hierdie punt maak Bultmann egter 'n geloofsprong. Ons kan wel glo dat God ons deur God se genade toelaat om op ons gebrekkige wyse van God te praat. Ons kan nie sékere kennis van God as sodanig hê nie, maar deur geloof kan ons seker daarvan wees dat God ons gebrekkige spreke oor God seker maak (Bultmann 1933:37). Terwyl Heidegger se syn met ons speel en ons mislei, glo Bultmann dat dit wat God vir ons ontsluit wel betroubaar en sinvol is. Hiermee ontken hy egter nie die differensie nie. Hierdie geloof is nie daarin gegrond dat God, soos in die geval van die Logos-ontologie, op so 'n wyse in die denke aankom dat God daarin opgaan nie. Die geloof is in die verborgenheid van God gegrond. Hierdie geloof het geen rasionele basis nie (Bultmann 1933:37). Die geloof word vanuit die differensie aangebied.

Terwyl Heidegger van mening is dat dit onmoontlik is om van die syn as sodanig te praat, praat Eckhart van God as 'n "synde" wat 'n onafhanklike bestaan in sigself het (Caputo 1986:184). Hy glo ook sekere dinge met betrekking tot die aard van God. Hierdie God is van so 'n aard dat 'n mens in 'n verhouding van liefde met God kan tree en dat 'n mens goeie dinge van God kan verwag (Caputo 1986:246). Die bron kan vertrou word en, in teenstelling met die onheilspellende syn van Heidegger, bring "kennis" van hierdie God vrede. Hierdie kennis van God is egter nie die soort kennis wat 'n subjek van 'n objek het nie. Die mens kan God nie deur sy rede bemeester nie. Hierdie kennis van God tree deur die genade van God vanuit God na vore (Caputo 1986:116).

\section{CHRISTOLOGIE EN DIFFERENSIE}

Caputo (1986:183) sien 'n proporsionele analogie ${ }^{6}$ tussen Heidegger se beskouing van die verband tussen syn en synde en Eckhart se beskouing van die verband tussen God en die menslike siel. Jones (1991:108) bespreek

\footnotetext{
${ }^{6}$ Deur 'n proporsionele analogie word 'n ooreenstemming tussen twee verhoudings uitgelig. Die proporsionele analogie tussen Heidegger en Eckhart se werk word soos volg geformuleer: "syn : synde :: God : siel" (Caputo 1986:183). Die proporsionele analogie tussen Heidegger en Bultmann se werk word soos volg geformuleer: "syn : denke :: God : gelowige denke" (Jones 1991:108).
} 
dieselfde fenomeen wanneer hy Heidegger en Bultmann se werk met mekaar vergelyk. Die verband tussen syn en denke (Heidegger) is soortgelyk aan die verband tussen God en gelowige denke (Bultmann). In hierdie paragraaf oorweeg ek hierdie insigte.

\subsection{Meister Eckhart}

Daar bestaan 'n proporsionele analogie tussen Eckhart se beskouing van die "verhouding" van God tot die siel en Heidegger se beskouing van die "verhouding" tussen syn en denke (Caputo 1986:183). Syn en denke hoort saam. Die een gaan nooit sonder die ander nie maar is sigself alleen in terme van die ander. Die syn is wesenlik dit wat op 'n verbergende wyse binne die denke aankom en die denke is wesenlik dit wat op 'n verbergende wyse vanuit die syn ontvang word (Heidegger 2001:62). Vir Eckhart staan die Vader en die siel op 'n soortgelyke wyse met mekaar in verband. Die wese van die Vader is om die Waarheid binne die siel gebore te laat word en die die siel is wesenlik dit wat die Waarheid vanuit die Vader ontvang (Caputo 1986:183). Eckhart identifiseer hierdie Waarheid met die Seun. Vir Eckhart is Christus egter geen synde nie. Christus is nie "iets" wat tussen die Vader en die siel staan nie. Die waarheid is die onmiddellike wedersydse toe-eiening van Vader en siel. Christus is nie 'n middelaar nie, maar ' $n$ bemiddeling. Elders stel Eckhart (Dominica I Post Trinitatem VI.2.61) dat God “... nur auf Gegenwärtiges wirkt und unmittelbar, nicht aber durch ein Mittel oder auf etwas, was von inm entfernt ist, wie die vollkommeneren Geschöpfe wirken". God en die siel verkeer saam in die spanning tussen die gedifferensieerde en ongedifferensieerde. Die mens is die wyse waarop God God self tot uitdrukking bring (Caputo 1986:165). Eckhart (In Festo s. Trinitatis IV.1.28) skryf dat "... wie er [God] selbst ununterschieden in seiner Natur und trotzdem von allen Dingen schlechthin unterschieden ist, so ist in inm alles zugleich in größter Unterschiedenheit und ununtershieden, und zwar erstens, weil der Mensch in Gott Gott ist [my aksentuasie]". In soverre die mens in God God is, is dit moontlik dat beide die gedifferensieerde en ongedifferensieerde in God kan wees. Die mens is die wyse waarop die ongedifferensieerde gelykgeldend gedifferensieerde is. Die Christusgebeure is die oorkoming van die ongedifferensieerde deur die gedifferensieerde en die oorkoming van die gedifferensieerde deur die ongedifferensieerde. Die Seun oorkom hierdie of daardie bepaalde wêreld en maak hierdie of daardie bepaalde wêreld terselfdertyd nuut (Dominica I Post Trinitatem VI.2.58).

Caputo (1986:157) wys daarop dat Heidegger se term "denke" en Eckhart se frase "die goddelike siel" 'n soortgelyke betekenis het in soverre beide dui op die samehorigheid van die denke en die bron van dit wat is. Die 


\section{Christus en die roos}

goddelike siel is 'n "ruimte" waardeur die openbaring van God ontvang word (Dominica I Post Trinitatem VI.2.57). Eckhart stel dat die Seun "in die Welt" gebore word, en nie "in diese Welt" nie (Dominica I Post Trinitatem VI.2.58). "Diese Welt" is die wêreld van dinge (Dominica I Post Trinitatem VI.2.58). Dit is die gedifferensieerde wêreld van dit wat geken en gekonseptualiseer kan word. "Die Welt" is 'n ongedefinieerde wêreld. Dit dui op die goddelike siel wat vir die aankoms van die ongedifferensieerde ontvanklik is. Eckhart (Pr. L 166, 36-38) beskryf dit soos volg: Die Seun word gebore '... "in die werlt", daz ist; in die liehten werlt, in die sêle, diu zemâle gescheiden ist von der ûzern werlt und ist in alle wîs gebildet nâch der götlîchen werlt'." Christus gebeur vanuit die ongedifferensieerde moontlikheid van die siel - dit wil sê: vanuit die "reine und einfache" siel. Dit beteken egter nie dat die siel deur Christus in die leegheid van die verborgenheid opgaan nie. Deurdat die Seun vanuit die verborgenheid gebeur, kom die Seun in die ontslotenheid van hierdie wêreld aan. Wanneer die Seun vanuit "die Welt" gebore word, word "diese Welt" nuut gemaak. Daarom stel Eckhart (Dominica I Post Trinitatem VI.2.58): “... [E]r sandte seinen Sohn in die Welt, das heißt, daß Gott auch in dieser Welt, 'uns die Macht' zugestand', 'Söhne Gottes' zu werden ..... Die Christusgebeure speel sigself af in die verskil van die ongedifferensieerde en gedifferensieerde - dit is: in die verskil van die verborgenheid en ontslotenheid.

Dat dit wat ongedifferensieerd is in dit wat gedifferensieerd is aankom, beteken egter nie dat eersgenoemde in laasgenoemde opgaan nie. Om deur Christus bevry te word, is vir Eckhart (Dominica VII Post Trinitatem XVII.2.168) om “... wahrlich befreit vom Jezt, das heißt vom Jezt, nämlich von der gegenwärtigen Zeit ..." te word. Eckhart (In Festo s. Trinitatis IV.2.30) stel tyd teenoor nie-tyd. Tyd dui op dit wat gedifferensieerd, konseptualiseerbaar en ontslote is. Nie-tyd of Ewigheid dui op die eenvoudigheid, ongedifferensieerdheid en verborgenheid van God. Indien Eckhart in die aanhaling hierbo alleen gestel het dat Christus ons van tyd vry maak, sou die bedoeling gewees het dat Christus ons van die gedifferensieerde as sodanig vry maak dat Christus ons van hierdie wêreld verlos. Eckhart kwalifiseer egter die term "tyd" deur te praat van "gegenwärtigen Zeit". Sodoende praat hy nie van tyd as sodanig of van 'n aardse epog nie, maar van die hier en nou van die mens se bepaalde historiese omstandighede. Die Christusgebeure speel sigself nie tussen die ongedifferensieerdheid van God en die gedifferensieerdheid van ' $n$ kosmos as sodanig af nie. In soverre God geen grond is nie, is daar in elk geval nie iets soos 'n kosmos as sodanig nie. Daar is alleen dit wat God oopmaak of geslote hou (In Festo s. Trinitatis IV.2.30). Die Christusgebeure speel sigself tussen die geslotenheid van God en die ontslotenheid van 'n bepaalde historiese situasie af. Sodoende blý die Christusgebeure altyd 'n 
ontsluitende verberging. Wanneer Eckhart stel dat Christus ons van ons "nou" bevry, voeg hy dadelik by dat ons maar altyd net in 'n spieël kyk (In Festo s. Trinitatis IV.2.30).

Met betrekking tot die genade van God en die lewe wat deur die Seun geskenk word, het Eckhart die volgende te sê: "[D]ies allein hat kein Warum ... sondern ist um seiner selbst willen, dank seiner selbst und frei. Daher (heißt es): 'wenn der Sohn euch befreit, werdet ihr wahrhaft frei sein"' (Dominica Prima Post Trinitatem; VI.2.59). En waarvan word ons waarlik vry? Ons word vry van die wêreld wat ons vir onsself daarstel - van die wêreld wat ons vanuit onsself en sonder God "lief" (Dominica I Post Trinitatem VI.2.59). Eckhart (In Solitate Corporis Christi V.1.43) is van mening dat die mens op twee wyses kan bestaan, naamlik: die goddelike toestand en die gevalle toestand. Die gevalle mens skep vir hom- of haarself 'n wêreld deur skepsels te "lief" - dit is: deur skepsels vanuit hom- of haarself te bepaal (Dominica I Post Trinitatem VI.2.59). Die gevalle mens skep vir homself 'n wêreld deur sy rede.

Gevallenheid is die toestand van "waarom". Die goddelike mens is, soos God, sonder "waarom". In sy kommentaar op Romeine 11:36 merk Eckhart (In Festo s. Trinitatis IV.1.21) op “... daß er [die skrywer] nicht sagt noch zufügt: "seinetwegen" ist alles ... weil Gott, und folglich auch der göttliche Mensch [my aksentuasie], nicht wegen eines Warum und Weshalb wirkt". Die goddelike mens lewe vanuit God. Hierdie mens word nie in terme van hierdie of daardie bepaalde wêreld gekonstitueer nie, maar bestaan as 'n leë en reine wêreld wat van alle maaksels geskei is (Pr 5a.l.80.7-11). Heidegger se kritiek op die beginsel van genoegsame rede toon merkwaardige ooreenkomste met dit wat Eckhart van die gevalle siel sê. Heidegger is van mening dat ons gedurige gevra na redes daartoe lei dat ons dit wat is, in ons eie subjektiwiteit begrond. Binne die raamwerk wat deur die beginsel van genoegsame rede daargestel word, bestaan niks wat nie deur ons eie rasionele oordele bevestig is nie (Caputo 1986:59). Sodoende word ons wêreld vanuit onsself bepaal. Die ander moontlikheid is om dit wat is en word, toe te laat om uit sigself na vore te tree (Caputo 1986:72). Heidegger noem hierdie oriëntasie van die denke "Gelassenheit". Hierdie term is vir die eerste keer deur Meister Eckhart gebruik om dieselfde saak aan te dui (Caputo 1986:174).

In die lig van ons teenswoordige konteks, is dit dalk nodig om iets oor Eckhart se beskouing van die historiese Jesus te sê. Die eerste ding wat in hierdie verband gesê behoort te word, is dat Eckhart nie die vraag na iets soos 'n historiese Jesus opneem nie. Eckhart het voor die tyd van historiese objektivisme en relativisme geleef. Hy stel die saak van die vleeslikheid van Jesus alleen in sy bespreking van die nagmaal aan die orde. Hierdeur bied hy tog 'n raamwerk waardeur die vleeslikheid van Jesus op 'n interessante wyse 


\section{Christus en die roos}

belig word. Hy vergelyk die vleeslikheid van Jesus met 'n spieëlbeeld (In Sollemnitate Corporis Cristi V.1.32). 'n Spieëlbeeld weerspieël iets van dit waarvan dit ' $n$ spieëlbeeld is sonder om self laasgenoemde te wees. So weerspieël die vleeslikheid van Jesus iets van Christus sonder om self Christus te wees. Soms kan 'n mens 'n spieëlbeeld sien sonder om dit waarvan dit ' $n$ spieëlbeeld is, te ken. So is dit dan ook dat mense soms in die vleeslikheid van Jesus vaskyk en Christus miskyk. Deur die nagmaal kan mense die brood en die wyn op 'n geestelike of op 'n vleeslike wyse ontvang (In Sollemnitate Corporis Cristi V.2.37). Diegene wat dit op 'n vleeslike wyse ontvang, mis die punt. Dit beteken egter nie dat die vleeslike op sigself genome onbelangrik is nie. Soos wat ' $n$ spieëlbeeld wel iets van dit waarvan dit is, omvat, so omvat die vlees en bloed van Jesus wel iets van Christus (In Sollemnitate Corporis Cristi V.2.37).

Wanneer 'n mens hierdie vergelyking ontologies interpreteer, gaan 'n interessante insig oop. Gadamer (2002:412-413) gee 'n interessante opsomming van die ontologiese struktuur van die beeld. ' $n$ Beeld is nie ' $n$ selfstandige ontologiese eenheid nie. ' $n$ Beeld is altyd relatief tot dit wat deur die beeld verbeeld word. Verder word dit wat deur die beeld weerspieël word nie suiwer en volledig deur die beeld teenwoordig gestel nie. 'n Beeld is nie ' $n$ kopie nie. lets anders as dit waarvan die beeld beeld is, is ook in die beeld teenwoordig. Deur die beeldingsgebeure word iets terselfdertyd ontsluit en verberg. In die beeldingsgebeure ontstaan daar ' $n$ kreatiewe spanning tussen die teenwoordigheid en afwesigheid van dit wat verbeeld word. Daar vind 'n bemiddeling plaas tussen dit wat verbeeld word en die beeld wat 'n oorsprong daarin het (Gadamer 2002:413). Die ontologiese struktuur van die beeldingsgebeure is dieselfde as die ontologiese struktuur van Eckhart se Christus. Soos wat dit wat verbeeld word sigself verbergend aanbied, is God die bron van die skepping deurdat God in God se differensiasie ongedifferensieerd bly. Christus is dit wat tussen die verborgenheid en ontslotenheid gebeur. Wanneer Eckhart die voorbeeld van 'n spieël gebruik om sy beskouing van die vleeslikheid van Jesus tot uitdrukking te bring, bly hy binne die raamwerk van sy Christus-ontologie. Jesus is deel van ons gedifferensieerde wêreld, maar op so 'n wyse dat Hy deel vorm van 'n "beeldingsgebeure". Deur die "beeldingsgebeure" van Christus is Jesus deel van God se "differensiërende" ongedifferensieerdheid en "ondifferensiërende" differensiasie. In hierdie lig bied Eckhart (In Sollemnitate Corporis Cristi V.2.37) se stelling dat die vlees van Jesus "... in sich enthält, was sie versinnbildet" 'n interessante moontlikheid. 


\subsection{Bultmann}

Dit is vir Bultmann duidelik dat die Logos van Johannes 1:1-2 nie alleen in terme van hierdie Ou Testamentiese opvatting van God se Woord verstaan kan word nie. In die Ou Testament is God se Woord 'n skeppende mag (Bultmann 1968:6). Deur God se Woord word die mens in die lewe geroep en word die "in-die-wêreld-wees" van die mens gedefinieer (Bultmann 1966:289). Die Woord van God word nie gesien as 'n mag wat 'n bestaan in sigself het nie. Volgens Bultmann (1968:8) behoort Spreuke se beskrywing van die Wysheid as 'n ewige entiteit naas God op metaforiese wyse verstaan te word. Die Woord van God is alleen die wyse waarop God in die wêreld van die mens handel. Sodoende word die Woord van God in terme van die temporaliteit van hierdie werklikheid verstaan (Bultmann 1968:7). Dit is 'n temporele gebeurtenis waardeur God die mens in sy of haar spesifieke historiese situasie aanspreek (Bultmann 1966:296). Deur spesifieke historiese handelinge word God in die wêreld van die mens teenwoordig en toeganklik (Bultmann 1968; vgl 1966:289). Johannes 1:1-2 maak dit duidelik dat die Logos nie alleen 'n temporele gebeurtenis is nie. Dit is 'n ewige wese wat buite hierdie wêreld 'n bestaan het (Bultmann 1968:7). Verder is die Logos van Johannes 1:1-2 meer as 'n handeling van God. In Johannes 1:1-2 word nie van die "Woord van God" gepraat nie, maar van "die Woord". Die term "Logos" funksioneer hier as 'n eienaam, en dit dui daarop dat die Logos as 'n selfstandige entiteit verstaan word (Bultmann 1968:7).

Binne die raamwerk van die Gnostiek word die term "Logos" gebruik ten einde 'n tussenganger of 'n middelaar tussen God en die Wêreld aan te dui. Vir die gnostikus het die Logos dus beide 'n kosmologiese en soteriologiese funksie (Bultmann 1968:10). Enersyds word die Logos-motief ingespan om die oorsprong van die kosmos vanuit God te verklaar. Andersyds verduidelik die Gnostiese Logos-motief ook hoe die siel uit die empiriese werklikheid wat van God vervreemd is na die goddelike sfeer kan terugkeer deurdat die Logos vlees word en die menslike sfeer betree. Volgens Bultmann pas hierdie Gnostiese taal in 'n sekere sin beter by die proloog van die Johannesevangelie as die Ou Testamentiese "Woord van God"-motief. Hy verwoord hierdie beskouing soos volg: "In der Sprache der gnostischen Mythologie redet der Joh-Prolog bzw. seine Quelle, und sein Logos ist jenes Zwischenwesen, das eine zugleich kosmologische und soteriologische Gestalt ist, jenes Gottwesen, das, von Uranfang her beim Vater existierend, um der Erlösung der Menschen willen Mensch ward" (Bultmann 1968:12). Anders as in die Ou Testament, is daar binne die Gnostiese denkraamwerk sprake van 'n ewige wese wat 'n bestaan naas God het. Verder is dit hierdie ewige wese wat binne die menslike sfeer teenwoordig word, en nie alleen 'n daad van God 


\section{Christus en die roos}

nie. Tog het die proloog nie dieselfde klem as die Gnostiek nie. In die proloog word die kosmologiese motief van die Gnostiek deur 'n soteriologiese motief oorskadu (Bultmann 1968:14). Die Gnostiese tendens om 'n kosmologiese verklaring vir die skeiding tussen God en wêreld te bied, is afwesig (Bultmann 1968:13,14). Binne die Hellenistiese verwysingsraamwerk is die Logos die grond van die kosmos. Die Hellenistiese Logos is die rede wat alles in die kosmos verklaar (Bultmann 1966:294). Verder behels die Hellenistiese kosmos 'n konseptuele inhoud of 'n essensie wat verstaan kan word (Bultmann 1966:292). Sodoende beskik alles in die kosmos oor die moontlikheid om gekonseptualiseer te word, en om uiteindelik in dié absolute konsep begrond te word. Anders gestel: Die Hellenistiese denker dink binne die raamwerk van die "waarom". Volgens Bultmann is die Logos van die proloog egter geen grond vir iets soos 'n kosmos nie. Die openingsfrase van die proloog stel nie dat die Logos die begin is nie, maar dat die Logos in die begin is. Hieruit lei Bultmann (1968:15) af dat die "outeur" die Logos buite daardie sfeer wil plaas wat vir die mens toeganklik is. Die stelling dat die Logos in die begin was, is volgens Bultmann (1968:16) 'n suiwere negatiewe beskrywing van die Logos. En, al wat hierdie karakterisering sê, is dat die Logos nie tot hierdie geskape en temporele werklikheid behoort nie. Die Logos is nie die grond in terme waarvan die wêreld verklaar kan word nie en dit het "... nicht etwas über den Ursprung der Welt zu lehren ...”. Die Logos bied geen antwoord op enige "waarom" nie.

Verder bied die proloog ook geen verklaring vir die onstaan van die Logos nie (Bultmann 1968:13). Daar is byvoorbeeld geen sprake daarvan dat die Logos deur 'n eminasieproses vanuit God onstaan nie. Deur die stelling dat die Logos by God was, word enige gedagte van 'n eminasieproses volgens Bultmann (1968:16) heeltemal uitgesluit. Soos wat die wêreld nie uit die Logos voortspruit nie, so spruit die Logos ook nie uit God voort nie. Deur die stelling dat die Logos by God was, kan die mitologiese uitdrukkingswyse van die proloog die indruk skep dat daar van twee goddelike wesens gepraat word. Hierdie moontlikheid word egter ook uitgesluit wanneer die "outeur" stel dat die Logos God was (Bultmann 1968:16). Volgens Bultmann (1968:17) is daar dus geensins van twee goddelike wesens sprake nie. Indien dit die bedoeling sou wees, sou die "outeur" die term "theios" gebruik het. God en Logos word aan mekaar gelyk gestel (Bultmann 1968:16). Die Ou Testamentiese motief van "die Woord van God" speel wel 'n rol in die proloog. Alhoewel die proloog die Logos as 'n selfstandige entiteit aan die orde stel, word die “... gnostische Kosmologie zugunsten des Schöpfungsglaubens verdrängt und das Interesse am Verhältnis der Menschen zur Offenbarung Gottes, also das soteriologische Interesse, beherrschend geworden ist 
(Bultmann 1968:14-15). Alhoewel die Logos van die proloog in 'n sekere sin "meer" is as die Ou Testamentiese "Woord van God", is dit met betrekking tot presies dieselfde saak "meer", naamlik dat God die mens in die lewe roep en die grense van sy of haar "in-die-wêreld-wees" daarstel (Bultmann 1966:289). Die Logos-motief in Johannes :1-3 sê iets oor die verhouding van die mens tot God.

In mitologiese taal beskryf die "outeur" die verband tussen God en Logos deur twee kontrasterende proposisies. Die Logos is by God, en by implikasie nie God nie. Maar, die Logos is God. Volgens Bultmann behoort ons hierdie stellinge nie te skei wanneer ons daarna luister nie. Die twee stellinge skep alleen die indruk van 'n kontradiksie omdat die "outeur" die grense van sy mitologiese taal bereik het (Bultmann 1968:18). Die himne is poësie, en kreatiewe taal word ingespan ten einde die bestaande linguistiese grense te oorkom. Die betekenis is nie in die proposisionele inhoud van die individuele stellinge geleë nie, maar word weerklank in die spanning tussen die twee uitsprake. Ten einde te verstaan, moet ons na hierdie spanning luister (Bultmann 1968:18). In hierdie spanning kom Ou Testamentiese "Woord van God"-motief en die Gnostiese Logos-motief bymekaar. God se Woord word in die Ou Testament verstaan as 'n daad waardeur God God self in die geskiedenis toeganklik maak, sonder om self in die geskiedenis op te gaan. So is ook die Logos ' $n$ daad wat God met betrekking tot die mens doen, sonder dat God in hierdie daad opgaan (Bultmann 1968:18). Die mitologiese taal van die Gnostiek stel die outeur egter in staat om meer te sê as die Ou Testamentiese "Woord van God"-motief. Die Logos is nie 'n kontingente daad van God nie. In mitologiese taal word dit as 'n ewige wese beskryf. Die Logos is God se absolute daad. Bultmann (1968:18) stel dit soos volg: "... [l]n der Ewigkeit und Einheit des göttlichen Willens ist Welt- und Heilsgeschehen begründet ...". Deur die daad wat God aan die mens doen, gaan God nie in die geskiedenis op nie. Tog is God se daad die Logos, naamlik dit wat aan God gelyk is. God is nie eers, en daarna hierdie daad nie. En, die skepping was nie eers en daarna die openbaring nie. Daarom stel Bultmann (1968:18): "Wer fragen würde: wie läßt sich von Offenbarung reden, solange es noch keine Schöpfung gab? - der würde das év óoxர́ mißverstehen und würde sich Gott und den Logos doch als zwei in der Zeit vorhandene Wesen vorstellen ...". God en Openbaring hoort saam. Openbaring is nie iets anders as God nie. In soverre die Logos aan God gelyk gestel word, is God sy Openbaring. Daarom stel Bultmann (1968:18): "Von Gott reden, heißt: von seiner Offenbarung reden; und von Offenbarung reden, heißt: von Gott reden."

Die Logos is nie alleen God nie. Die Logos is ook wêreld. Wanneer daar in Johannes 1:3 gestel word dat alles deur die Logos in die lewe geroep 


\section{Christus en die roos}

is, beklemtoon Bultmann (1968:19) die feit dat daar in Johannes 1:1-4 van geen dualisme sprake is nie. God is nie een ding en die skepping 'n ander ding nie. Die Logos is vir Bultmann geen tussenganger tussen God en skepping nie. Die Logos is God in soverre God Homself openbaar (Bultmann 1968:20). In hierdie verband stem Bultmann en Eckhart saam. Soos Eckhart (Dominica I Post Trinitatem VI.2.61) is Bultmann van mening dat die Tweede Persoon van die Drie-Eenheid geen middelaar is nie. Daar is geen "tussenruimte" vir 'n tussenganger nie. Bultmann (1968:20) stel die saak soos volg: "Er [die Logos] ist nicht, wie der Logos Philos oder der Nous Plotins, ein Vermittler zwischen der Welt und der transzendenten Gottheit, sondern er ist Got selbst, sofern er sich offenbart". God en skepping staan in 'n onmiddellike verhouding tot mekaar. Deur die Logos-motief van Johannes 1:1-4 word die aard van hierdie verhouding verwoord. En, hierdie Logos-motief het betekenis in terme van die spanning tussen die Gnostiese Logos-motief en die "Woord van God"-motief wat daarin opgesluit lê. God kom in sy volkomenheid in die geskiedenis aan, maar gaan nie sodoende in die geskiedenis op nie. Anders gestel: Die Logos dui op God se verbergende aankoms in die geskiedenis en die geskiedenis se verbergende ontvangs van God.

Die "alles" van vers drie dui op die mensdom (Bultmann 1968:20). Vers vier se stelling dat die Logos die lewe en die lig is, is dus op die mens van toepassing (Bultmann 1968:21). Dit beteken dat die Logos nie die bron is van 'n wêreld van objekte wat voorhande is nie. Die mens is nie een objek wat tussen ander objekte voorhande is nie (Bultmann 1968:20; vgl 1966:59). Die mens is daardie soort synde wie se eksistensie met betrekking tot sigself ontslote is en wat vir sy of haar eie eksistensie verantwoordelik is (Bultmann 1961b:193). Dit beteken dat daar altyd 'n bepaalde selfverstaan met menslike eksistensie gepaard gaan (Bultmann 1961b:194). As die bron wat die mens in die lewe roep, is die Logos gelykgeldend die moontlikheidsvoorwaarde van die mens se selfverstaan (Bultmann 1968:22; vgl: 1966:289). Die moontlikheid van die mens om sigself in sy of haar wêreld te verstaan, is in God gegrond (Bultmann 1968:24). Anders gestel: Die mens is die moontlikheid om sigself vanuit God te verstaan of nie te verstaan nie (Jones 1991:68). Die verbergende aankoms van God en die verbergende ontsluiting van Dasein hoort saam. En, hierdie verbergende ontsluitingsgebeure is niks anders as die Logos nie. Die Logos is geen synde wat tussen God en mens bestaan nie, maar die gebeure waardeur God die mens as selfverstaan in die lewe roep. Daarom kan Bultmann (1968:22) stel dat “... [i]m ursprünglichen Sinne is Licht nicht ein Beleuchtungsapparat, der Dinge erkennbar macht, sondern die helligkeit, in der ich mich je befinde und zurechtfinden kann ...”. 
Die heilsopenbaring van Jesus is in hierdie oorspronklike moontlikheid van Dasein om sigself in die "Lig" van God se openbaring te verstaan, gegrond (Bultmann 1968:25). Anders gestel: Dat God God self in God se volkomenheid openbaar, is die moontlikheidsvoorwaarde vir God se aankoms in spesifieke historiese omstandighede. Hierdie oorspronklike moontlikheid is gelykgeldend ook 'n verlore moontlikheid. Die heilsopenbaring van Jesus bring die verlore moontlikheid van die skeppingsopenbaring terug (Bultmann 1968:25). Wanneer gaan hierdie oorspronklike moontlikheid verlore? Die heilsopenbaring van Jesus kan vir die mens "... zum Verderben werden, wenn er aus ihm die Kriterien gewinnen will, um zu urteilen, wie ihm Gott begegnen, wie Offenbarung Wirklichkeit werden müsse (Bultmann 1968:39). Die mens kan sigself nie verstaan wanneer hy homself en God binne 'n rasionele ordening plaas en probeer verklaar nie (Bultmann 1966:58-60). Deur so 'n ordening te skep, probeer die mens die werklikheid in homself grond. Die menslike rede word die kriteria waarvolgens dit wat is, bepaal word. Die mens kan sigself en God alleen verstaan wanneer die mens instem om sigself en God nie te verstaan nie - dit wil sê: wanneer die mens nie kriteria daarstel waarvolgens hy God se Woord beoordeel nie (Bultmann 1966:64). Die outentieke mens is dié een wat vry is van eiewaan en wat oop is vir 'n toekoms wat vanuit God bepaal word (Bultmann 1961c:206; vgl Jones 1991:77). Die outentieke mens is gereed vir die roos. 'Die Ros' ist ohn' warum, sie blühet weil sie blühet, Sie acht't nicht ihrer selbst, fragt nicht, ob man sie siehet" (CW, I, 289 in Caputo 1986:61). God het God self reeds openbaar, en hierdie Openbaring steur sigself nie aan die rasionele kriteria van die mens nie.

Die verband tussen die historiese Jesus en God is dieselfde as die verband tussen die oorspronklike moontlikheid van die mens om sigself te verstaan en die verwesenliking van hierdie moontlikheid in konkrete historiese situasies. Bultmann (1961b:207) stel dat die ewige kwaliteit van die Woord geleë is in die werklike teenwoordigheid daarvan deur spesifieke momente. Die oorspronklike moontlikheid van die mens om sigself te verstaan, bly ' $n$ ewige moontlikheid met betrekking tot die geskiedenis. Daarom stel Bultmann (1961b:206-207) dat God ons ter alle tye en op alle plekke ontmoet. As gevolg daarvan dat die mens in sigself vaskyk, mis die mens egter hierdie oorspronklike moontlikheid. Sodoende is dit nodig vir die Woord om vlees te word. Die oorspronklike moontlikheid van die mens om sigself te verstaan, word alleen verwesenlik wanneer die mens se oë in sy spesifieke situasie vir hierdie oorspronklike moontlikheid oopgaan (Bultmann 1961b:207). In 'n konkrete situasie daag God die wyse waarop die mens sigself op daardie tydstip verstaan, uit. Die Woord wat God binne die menslike sfeer spreek, is 


\section{Christus en die roos}

nie sonder inhoud nie. Die inhoud daarvan is egter nie van so 'n aard dat dit 'n universele waarheid is nie. Die inhoud is van so 'n aard dat dit die wyse waarop die mens sigself op ' $n$ bepaalde tyd verstaan, uitdaag (Bultmann 1966:306). Die een wat hierdie oproep gehoorsaam - wat glo dat God hom of haar uitdaag - word oopgemaak vir God se openbaring en word sodoende bevry van die wêreld wat hy of sy vir hom- of haarself geskep het (Bultmann 1961b:206). Sodoende ontstaan daar dan 'n outentieke selfverstaan. Die Logos en Jesus hoort saam en gebeur saam. Vanuit die Logos daag Jesus sy tydgenote uit, en deur die uitdaging van Jesus word die Logos verwesenlik. Jesus en Logos is nie dieselfde in soverre Jesus die essensie van die Logos op die een of ander wyse sou bevat nie. Jesus en Logos hoort saam in soverre beide deel is van die eskatologiese gebeure waardeur God in die geskiedenis aankom sonder om daarin op te gaan.

\section{CHRISTUS EN DIE ROOS}

Hierdie artikel het hopelik geen konklusie nie, sodat dit die grond vir geen gevolgtrekking is nie. Hopelik het God op 'n verbergende wyse deur hierdie artikel aangekom. En, hopelik is hierdie artikel soos die roos.

Die Ros' ist ohn' warum, sie blühet weil sie blühet, Sie acht't nicht ihrer selbst, fragt nicht, ob man sie siehet".

\section{Literatuurverwysings}

Albert, K 1987. Das Sein ist Gott: Zur philosophischen Mystik Meiter Eckharts, in Zu dir hin: Über mystische Lebenserfahrung Von Meister Eckhart bis Paul Celan. Frankfurt: Insel Verlag

Bultmann, R 1941. Das Evangelium des Johannes. Göttingen: Vandenhoeck \& Ruprecht.

Bultmann, R 1933. Welchen Sinn hat es, von Gott zu Reden?, in Glauben und Verstehen. Tübingen: Verlag von J C B Mohr.

Bultmann, R 1966. The Word of God in the New Testament, in Faith and understanding. New York: Harper \& Row.

Bultmann, R 1969a. New Testament and mythology, in Kerugma and myth: The theological debate.New York: Harper \& Row

Bultmann, R 1969b. A reply to the theses of J Schniewind, in Kerugma and myth: The theological debate. New York: Harper \& Row.

Bultmann, R 1969c. Bultmann replies to his critics, in Kerugma and myth: The theological debate. New York: Harper \& Row.

Caputo, J D 1986. The mystical element in Heidegger's thought. New York: Fordham University Press. 
Descartes, R 1911. The principles of philosophy, in The philosophical works of Descartes, vol 1, tr by E S Haldane \& G R T Ross. Cambridge: Cambridge University Press

Eckhart, Meister 1956. Dominica Prima Post Trinitatem, übersetzt von Benz E, Decker B \& Koch J. Stuttgart: Kohlhammer Verlag.

Eckhart, Meister 1956. Dominica Septima Post Trinitatem, übersetzt von Benz E, Decker B \& Koch J. Stuttgart: Kohlhammer Verlag.

Eckhart, Meister 1956. In Festo s: Trinitatis, übersetzt von Benz E, Decker B \& Koch J. Stuttgart: Kohlhammer Verlag.

Eckhart, Meister 1956. In Sollemnitate Corporis Christi, übersetzt von Benz E, Decker B \& Koch J. Stuttgart: Kohlhammer Verlag.

Heidegger, M 1962. Being and time, tr by Macquarrie, J \& Robinson, E. Oxford: Blackwell

Eckhart, Meister 2001. Identität und Differenz, tweetalige editie. Amsterdam: Boom.

Eckhart, Meister 1969. Discourse on thinking, tr by Anderson J M \& Freud E H New York: Harper \& Row.

Jaspers 1983. Plato. Munchen: Piper.

Jones, G 1991. Bultmann: Towards a critical theology. Cambridge: Polity Press.

Musa, W 1987. Logos und Mysterium, in Zu dir hin: Über mystische Lebenserfahrung Von Meister Eckhart bis Paul Celan. Frankfurt: Insel Verlag

Philo 1993. The works of Philo: Complete and unabridged, tr by C D Yonge.

Peabody, MA: Hendrickson.

Plato 1971. Phaedo. Loeb Classical Library.

Plato 1953. Republic. Loeb Classical Library. 